\title{
Bridging Fibrosis
}

National Cancer Institute

\section{Source}

National Cancer Institute. Bridging Fibrosis. NCI Thesaurus. Code C153815.

A morphologic finding indicating the presence of fibrous bands connecting portal tracts, portal tracts and centrilobular spaces, or centrilobular spaces in a liver tissue sample in a patient with evolving cirrhosis. 